\title{
Interethnic relations and language variation: language use and identity negotiation among Namibian Coloureds and Whites in interactional settings
}

\author{
Gerald Stell \\ Centre for Linguistics, Vrije Universiteit Brussel, Pleinlaan 2, 1050 Elsene, Belgium/ \\ Department of Afrikaans, University of Pretoria, Private Bag X20, 0028 Hatfield, South Africa \\ E-mail: Gerald.Stell@vub.ac.be
}

Herman L. Beyer

Department Language and Literature Studies, University of Namibia, Private Bag 13301, Windhoek, Namibia

\begin{abstract}
In this paper we present a case study of interethnic relations through language variation involving two population groups supposedly belonging to one single speech community, namely the White and Coloured Afrikaans speakers of Namibia. The specific question that we wish to tackle in reference to that community is the extent to which Coloured and White identities are differentiable via linguistic means and how those identities are negotiated in intergroup settings where Coloured and White Afrikaans speakers are in mutual contact. The methodology used to answer this question is largely based on Communication Accommodation Theory (CAT), which entails the characterization of intergroup language variation in terms of convergence, divergence and maintenance, as well as the characterization of speakers' group identities in terms of 'subordinate' and 'superordinate' identities.
\end{abstract}

Keywords: Afrikaans; code-switching; identity; Coloureds; Namibia

\section{Introduction}

The study of interethnic relations from the vantage point of linguistic phenomena has been undertaken from a variety of theoretical perspectives addressing themselves with social identity, among which Communication Accommodation Theory (CAT) is prominent. In this respect, CAT has typically dealt with interactional settings involving socially contrasting ethnic groups. In such settings, CAT characterizes language variation as convergence, divergence or maintenance in the interest of identification or dissociation.

A new case study of interethnic relations through language variation that we wish to offer here involves two population groups supposedly belonging to one single speech community, namely the White and Coloured Afrikaans speakers of Namibia. The specific question that we wish to address in reference to that community is how Namibian Coloured and White identities are negotiated in intergroup settings by taking a CAT perspective. To what extent can linguistic phenomena observable in White-Coloured interactions be accounted for in terms of divergence, convergence and maintenance as defined in CAT? What are the limitations of those CAT 
concepts in accounting for identity processes as observable within White-Coloured interactions in the Namibian context?

This paper is organized as follows. After providing a sociolinguistic characterisation of White and Coloured Afrikaans speakers in the Namibian context, we give a brief overview of CAT and of the possible limitations of its methodology in accounting for language variation in Namibia's Afrikaans speech community. We then go on to present our methodology and general hypotheses. This precedes a presentation of interview data and a quantitative and qualitative analysis of speech variation in interactional settings involving Whites and Coloureds separately, as well as conjointly. The analysis of Whites and Coloureds in interaction is broken down into overviews of convergence and divergence in which attention is regularly paid to maintenance. The final section will assess the relevance of the obtained CAT account to the characterisation of White and Coloured identities in a broader analytical context in which not only patterns of language variation but also participants' discourses are involved.

\section{Coloureds, Whites and language in South West Africa/Namibia}

Namibian society is the product of a colonial past in which South Africa was intimately involved. The south of modern day Namibia saw, from the late $18^{\text {th }}$ century up until the end of the precolonial period, the gradual arrival of various Cape Dutch-speaking population groups from the Cape Colony, namely the Oorlams (clans of westernised Khoikhois), followed by the Trekboeren (small groups of White pastoralists) and, finally, the Basters (a group of families with a mixed European-Khoikhoi background). The advent of German colonial rule (18841915) put restrictions on continuous immigration from South Africa to Namibia, although parties of White Cape Dutch-speaking farmers were allowed in - especially in the wake of the $2^{\text {nd }}$ Boer War (Wallace \& Kinahan 2010). The proclamation of the South African mandate over what had been Südwestafrika (Southwest Africa, hereafter SWA), in 1919, opened the gates to more significant immigration from what had meanwhile become the Union of South Africa (1919-1961).

The label "White" was applied to people of European descent throughout the German colonial time and the South African mandate. Cape Dutch-speaking Whites formed a minority in the White population of SWA, where they were referred to as Buren (Schnee 1920: 255), and were mostly farmers concentrated in the arid southern districts. With the rise of Afrikaner nationalism in South Africa, and of Afrikaans as an ethnolinguistic identifier among White Cape Dutch speakers, the ethnolinguistic label Afrikaner had become a widespread, selfascribed, category by the time of the South African mandate. The Afrikaner element in SWA's White rural population became generally dominant in the wake of WWI as a result of settlement policies of which White Afrikaans-speaking farmers were the main beneficiaries (Coetzee 1982: 105, 112, 172). The 1981 demographic census for SWA - the last official census involving Namibia's current territory that took account of ethnic categories - found that $71 \%$ of local Whites were Afrikaners and 17\% were Germans (Weigend 1985: 159). The 1960 census for SWA ${ }^{1}$ estimated the territory's Whites to amount to $13.97 \%$ of the total population (Odendaal 1964).

\footnotetext{
${ }^{1}$ The results of the 1981 census were never made public, except for data on language use, detailed in Prinsloo (1982). All data on the 1960 census quoted in this paper stem from the Report of the Commission of Enquiry into SWA Affairs/Verslag van die Kommissie van ondersoek na aangeleenthede van Suidwes-Afrika, 1962-3 (Odendaal 1964).
} 
The label "Coloured" as it is now applied in Namibia originates in colonial South Africa, more precisely in the period following the $2^{\text {nd }}$ Boer War (1899-1902). It could have emerged as a self-ascribed category in opposition to both "White" and "Native" (or "Black") (Adhikari 1996: 9, 2005). The term "Coloured" spread further as a result of being used in official South African statistics from 1921 onwards to refer to those non-Whites who were regarded as not falling within the categories "Native" or "Indian" (Horrell 1970: 15). Its definition in SWA has, however, been more restrictive. In German times, many of those who later came to be referred to as Coloureds were known as Mischlinge, that is, individuals of mixed German and local nonWhite parentage, thus not including the Rehoboth Basters (Sippel 2004: 138). During the South African mandate, the label Coloured was used to refer not only to those individuals (referred to as "local Coloureds" by the administration), but also to Basters and fresh arrivals from the Cape or Walvis Bay ${ }^{2}$ (referred to as "Cape Coloureds" by the local administration), who settled in increasing numbers in the urban centers (especially in the early 1960s; cf. Bruwer 1964: 226). However, since the so-called local Coloureds have tended to live among Hereros and to assume the identity of that population group, and since the Basters had successfully petitioned the South African government for a separate status (Britz et al. 1999: 42-5), the label "Coloured" increasingly came to refer exclusively to Cape Coloureds in both official and popular nomenclature (Zingelwa 1999: 28). On these grounds, we will henceforth be using the label "Coloured" in that restricted sense, i.e. referring only to Cape Coloureds.

The language data from the 1981 census for SWA show that $92 \%$ of SWA Coloureds (that is, excluding Basters) spoke Afrikaans as a home language (Prinsloo 1982). The 1960 census for SWA estimated the territory's Coloured population to amount to $2.42 \%$ of the totals (Odendaal 1964).

Except for the data in Odendaal (1964), socioeconomic and linguistic data on Namibian Whites are largely non-existent. Because no census conducted since Namibian independence has taken account of ethnic categories, there is no available information regarding the respective socioeconomic statuses of Namibia's White and Coloured communities. South African statistics may provide an indirect indicator in this regard. The 2001 census revealed that Whites fared significantly better than Coloureds in terms of employment, income and education (Statistics South Africa 2001). One may assume on the basis of the similar socio-historical heritage shared by South Africa and Namibia that Namibian Whites may also still occupy a socio-economically privileged position. Reconstructing White Afrikaans-speaking identity in post-independence Namibia, without referring to South African Whiteness studies, poses a challenge. According to Steyn (2005), the perception among post-apartheid South African Whites that they form a minority has caused a 'diasporic' English-speaking dimension to develop in their construction of 'Whiteness', which could be correlated with their low levels of identification with the idea of a South African nation (Roefs 2006: 81-2). But in the specific case of Afrikaans-speaking Whites, one may wonder whether any such diasporic identification may not be subordinated to a collective commitment to preserving the Afrikaans linguistic heritage, since the promotion of Afrikaans formed a guiding principle of Afrikaner nationalism (Zietsman 1992). In Namibia, where the visibility of Afrikaans - especially as an instruction medium - has decreased dramatically in the wake of the country's independence in 1990 (Beuke 1997), no account is available on language attitudes among White Afrikaans speakers. It is also questionable to what

\footnotetext{
${ }^{2}$ Walvis Bay formed a British enclave within Südwest-Afrika. A number of Cape Coloureds resided there before the proclamation of the South African mandate (Wilken \& Fox 1978).
} 
extent Namibian Whites in general identify with Namibia as a nation in comparison with other groups.

SWA Coloureds ${ }^{3}$ acquired the contours of a distinct population group as non-White education in SWA became ethnically segregated as of 1958, and separate residential areas were created for the purposes of Coloured education (e.g. Khomasdal in Windhoek; cf. Zingelwa 1999: 29, 33). Post-independence data are available in the form of the anthropological study conducted by Betzdorf (2007) among Windhoek Coloureds. This study found that in a local perspective Coloured ethnicity is defined linguistically (i.e. Afrikaans is the dominant language), spatially (i.e. with Khomasdal as point of reference), and on the basis of skin colour. Coloured ethnicity tends to be negatively defined in relation to ethnic 'Others', i.e. as an entity deprived of 'culture', and standing 'in between' Whites and Blacks, with an enduring sense of being discriminated against. It further suggests that Coloureds have tended to value their Western heritage, even though this does not translate in distinctive social proximity to Whites. Coloureds tend to maintain overwhelmingly Coloured social networks, in which Blacks and Whites might occasionally be involved, but to a limited extent. Betzdorf's account of Namibian Coloured ethnicity is reflected in accounts of South African Coloured ethnicity in the conflicting tendencies of rejecting the label "Coloured" (by discursively associating with either Whites or Blacks) yet valorising 'Colouredness' through 'Colouredism' (cf. e.g. Adhikari 2005).

Data on language variation among Namibian White and Coloured Afrikaans speakers are quite scarce. It is assumed that the southern part of Namibia, where Basters and Coloureds form the majority of Afrikaans speakers, is located within the so-called Orange River Afrikaans historical dialect zone (Du Plessis 1987). It is also assumed that varieties from the Western Cape are also represented, probably more spoken by Coloureds than by Basters (Beuke 1997). White Afrikaans speakers cannot be traced down to any specific region of South Africa, and may have imported different regional varieties. According to Stell (2009), there is a quantitative gap between Coloured and White patterns of Afrikaans usage in the Windhoek region pointing towards divergence across generations, with Whites generally remaining closer to Standard Afrikaans, seen as historically possessing more social prestige than Afrikaans Coloured varieties (Webb 1989).

Despite suggestions that they are not socially integrated and that they are linguistically diverging, most Namibian Whites and Namibian Coloured are sociolinguistically related by being L1 speakers of Afrikaans, and also by being exposed in similar terms to Namibia's English-centred language-in-education policy ${ }^{4}$. They may also be ideologically related by virtue of sharing a status of ethnic and linguistic minority in a Black-dominated polity of which the linguistic attribute is English. It is, however, important at this stage to emphasize that Coloureds might feel more related to the post-apartheid order by virtue of being 'non-White',

\footnotetext{
${ }^{3}$ Excluding Basters, on whom substantial research is available. A historical account of the Baster people is available in the form of Britz et al. (1999). For a contemporaneous account of identity construction among Basters, see Kjæret (2003).

${ }^{4}$ It is important to briefly describe Namibian language-in-education policy. The official phrasing of that policy allows for the option of using the native language or the regionally dominant language as a medium of instruction from Grade 1 up to Grade 4, after which English is to be phased in as the sole medium of instruction. The official phrasing of the policy also makes provision for the exclusive use of English throughout the curriculum. For further details, see Tötemeyer (2010) and Wolfaardt (2001). Data on levels of Afrikaans-English bilingualism among Namibia's Afrikaans speakers are absent, but an impressionistic account is available in Beuke (1997).
} 
and therefore theoretically favoured over Whites in affirmative action schemes ${ }^{5}$. The broad question we wish to ask is how the combination of tensions and commonalities between White and Coloured Afrikaans speakers is expressed in contexts of social interaction involving both groups. As will be made clear in the next section, language use can theoretically provide a central clue in the reconstruction of interethnic relations.

\section{Ethnicity and language variation: convergence and divergence}

It is generally acknowledged that ethnicity is one of the basic components of social identity. It is also generally acknowledged that ethnicity can be identified linguistically, even though it does not possess as much predictive power as age, gender and social class (cf. Fought 2002: 452; Labov 2001: 105-13). Finally, it is acknowledged, most especially in constructionist perspectives, that ethnicity is linguistically negotiable depending on the situational context (cf. for example, Bailey 2007). One of the typical contexts in which the negotiation of ethnicity by linguistic means has been observed is that of interethnic encounters; that is, a context where the boundary between 'us' and 'them' can be expected to be most salient. Such encounters can have various linguistic outcomes. Among the various possible scenarios, members of a group A may be seen to converge with the usage typical of members of another group B, while members of group B do not show as much disposition for converging with the usage typical of members of group A. This scenario is illustrated by Bell's (2001: 152-6) study of the New Zealand Maori interacting with Pakeha (New Zealanders of British ancestry): Whereas the former visibly adjust at a linguistic level, the latter do not. This scenario suggests an unequal power relation between the two ethnic groups, but Bell's study recognizes this only a posteriori. Among all sociolinguistic frameworks, CAT is the only one that provides a descriptive and predictive typology that correlates scenarios of language variation in interactional settings with specific intergroup relations, which - despite limitations - makes it an obvious theoretical choice for investigating ethnicities in interaction.

In the latest developments of CAT, as presented in Gallois et al. (2005), communication patterns are broadly summarized as accommodating and non-accommodating strategies, which are illustrated by convergence, divergence and maintenance within the interaction. In situations of contact involving socially contrasting groups, CAT assumes the existence of a linguistic boundary, but emphasizes its negotiable nature. The type of negotiation to which that linguistic boundary lends itself reflects specific dispositions among the participants toward maintaining their identities (social or personal). In other words, linguistic symptoms of an individual A (from social group A) diverging from an individual B (from social group B), within a given interaction, may index A's initial orientation toward non-accommodation through divergence from the perceived linguistic characteristics of B's group. That same initial orientation may be motivated by a salient negative intergroup history between groups $\mathrm{A}$ and $\mathrm{B}$, and the individual A, identifying strongly with his/her group (e.g., perceiving his/her group's vitality to be low and making insecure social comparisons with group B), divergence by individual A is characterized as 'downward' divergence. By contrast, B's perception of his/her own group's vitality as being high usually results in the maintenance of his/her group patterns of usage. Initial orientations can be transformed, however, during the interaction, as a result of a changing perception by the participants of the salience of social identities. If social identities come to lose salience in the eyes of A in favour of, for example, interpersonal motives or

\footnotetext{
${ }^{5}$ Affirmative Action in the Namibian context does not, however, come with ethnic labels. It is officially aimed at redressing wrongs in favour of 'Previously Disadvantaged Namibians' without any further specification (Ganaseb 2008: 13, van Rooyen 2000).
} 
cognitive motives of interpretability, then A might engage in linguistically accommodating B in the form of 'upward' convergence. Similarly, B might in such contexts engage in 'downward' convergence with A, which might be perceived as inappropriate by A if social identities are salient in his/her eyes (cf. Galois \& Callan 1991: 250-1, Giles 1979).

The main principles of CAT find practical illustrations in a range of studies dealing with intergroup interactions in ethnically tense situations. Giles $(1979,1978)$ classified instances of African Americans converging with or diverging from European Americans as instances of upward convergence and downward divergence, respectively. The Canadian situation provided examples of downward convergence of English-speakers with French-speakers attempting to speak English. It also provided examples of maintenance with a depiction of Quebec Englishspeakers keeping to English when addressed in French by Quebec French-speakers (Genesee \& Bourhis 1988: 229-230). One common characteristic of those studies is the preliminary assumptions they make with regard to the social status of the respective ethnolinguistic groups involved. African Americans and Canadian French speakers are viewed as subordinate groups on the grounds of their socio-economically marginal position, which then justifies labelling convergence and divergence between these groups and the dominant Others (i.e. European Americans and Canadian English speakers in these cases) as pointing downward and upward, respectively (Giles 1978, 1979). Those preliminary assumptions are facilitated by the measurement of what proponents of CAT call "ethnolinguistic vitality", broadly defined as "that which makes a group likely to behave as a distinctive and collective identity within an intergroup setting" (Giles, Bourhis \& Taylor 1977: 308). It is objectively measured along the axes of demography, institutional control, and status variables related to a language community's social prestige, its sociohistorical status within the state, and the prestige of its language and culture. Subjective ethnolinguistic vitality, on the other hand, is measured on the basis of group members' assessments of in-/out-group vitality along the same axes as those presented above.

Using such criteria for assessing the ethnolinguistic vitality of Coloured and White Afrikaans speakers may be useful while simultaneously highlighting the limitations of CAT. On the basis of suggestions that Namibian Whites still occupy the top echelons of Namibia's socio-economic ladder, one might want - for the purpose of predicting intergroup dynamics of speech variation along the CAT paradigm - to make the assumption that White Afrikaans speakers form a dominant ethnolinguistic group from a Coloured perspective (even though high socioeconomic status is just one among other criteria that define a dominant group). But there are suggestions that such an assumption might be ill-founded. If White Afrikaans speakers may alongside German speakers have been (and may perhaps still be) considered to be the dominant ethnolinguistic group in the pre-independence Namibian/SWA context (in which case linguistic convergence of non-Whites with White Afrikaans speakers would fit a description as 'upward' divergence), the redistribution of socio-political power in favour of non-Whites concomitant with the rise of a prestigious - yet not ethnically definable - Namibian non-White English-speaking identity that occurred after independence calls for a re-appraisal of ethnolinguistic power relations in the Namibian context. Establishing which group is more dominant, namely the White Afrikaans speakers, or the rising 'non-White elite', might be crucial for accurately interpreting the identity-relevance of linguistic convergence, divergence or maintenance in Coloured-White interactions.

Discursive approaches, collectively referred to as Discourse Analysis (DA) share the conviction that discourse - and thus qualitative data - is of central importance in reconstructing 
identities, collective and individual, and by implication in reconstructing what is 'us' and what is 'them'. Methodological examples of CAT-based analyses with a qualitative dimension come in the form of Burt's qualitative reconstruction of perceptions of linguistic convergence (1994). Examples of identity reconstruction via DA are, on the other hand, usually not integrated in a CAT approach. One case study of ethnicity in interaction - in which linguistic convergence and divergence as well as discourse are treated centrally - can be found in the form of SchillingEstes' study of African American and Lumbee identities ${ }^{6}$ (2004). We take the view here that Coloured-White relations as observable in interactional settings are best investigated through an approach in which the broad principles of CAT and DA are integrated in the interest of reconstructing collective power relations against the specific background of the Namibian context.

\section{Methodology}

A total of four Coloured students and two White students (presented in more detail in the following section) were recruited along the Friend of a Friend approach (Milroy 1987) to take part in what was vaguely presented as an experiment on 'communication patterns'. The informants were all individually interviewed before being asked to take part in interactions, for which no instructions were given apart from that of speaking as is usual in informal settings. The interactions comprised one White in-group conversation involving the two White participants, one Coloured in-group conversation involving all four Coloured participants, and one intergroup interaction involving both White participants as well as two of the four Coloured participants. The Coloured and White participants were not mutually acquainted other than by sight. In order to reduce the Observer's Paradox, the researcher was not physically present during the interactions. Each interaction lasted 1.30 hours and yielded totals of words ranging from roughly 4000 up to 6000 . The interactions were followed by a series of individual interviews, in which the participants were asked for feedback on the group interactions.

The analysis we intend to conduct starts with an analysis of the interviews preceding the interactions. The preliminary interviewing stage aimed to elicit self-categorisations, in general, and perceptions of ethnolinguistic Others. On that basis it seeks to define how Coloureds and Whites rank themselves and each other in terms of ethnolinguistic prestige. Besides, it seeks to establish what might be accommodative norms in interethnic interactions as well as initial orientations among the participants towards accommodating the perceived linguistic group characteristics associated with the ethnolinguistic Other.

The speech data analysis we intend to conduct is comprised of two main stages. First, a contrastive analysis is conducted of speech patterns in the in-group context (i.e. Coloureds in interaction with Coloureds vs. Whites in interaction with Whites), followed by an analysis of speech patterns in the Coloured-White interaction. The general purpose of this analysis is to establish what linguistic in-group norms are, and in what way those linguistic in-group norms are adjusted in contexts involving out-group members.

Besides phonological and lexical variances, potentially contrasting linguistic features include a range of morphosyntactic variables and grammatical and conversational patterns of Afrikaans-English code switching (CS). Those Afrikaans morphosyntactic variables that are of

\footnotetext{
${ }^{6}$ Lumbees and African Americans form distinct ethnic groups in the context of North Carolina. They both share an experience of exclusion from European American society, being more or less similarly relegated to the status of low status groups (Schilling-Estes 2004: 165-8).
} 
particular relevance to a contrastive analysis involve variants described as typically pertaining to 'Coloured' varieties in descriptive literature, and established as such in a Namibian perspective by Stell (2009). Those variants are as follows:

- $\quad$ Possessive pronouns adjoined with the clitic particle se, such as onse/ons se (Std. Afrikaans ons "our"), julle se (Std. Afrikaans julle "your-PLURAL") and hulle se (Std. Afrikaans hulle "their", see Ponelis 1993: 230).

- $\quad$ The irregular formation of the past participle for verbs with an atonic prefix (e.g. gevertel "told" instead of the standard form vertel) or with double infinitives (e.g. hy het gegaan slaap instead of the standard form hy het gaan slaap "he went to sleep", see Ponelis 1993: 421).

Other morphosyntactic variables, the distribution of which is established as cross-ethnic rather than as ethnically exclusive (Stell 2009), may lend themselves to a quantitative contrastive analysis on account of their high frequency, namely the non-standard single negation (e.g. ek het dit nie gesê "I didn't say that") instead of the standard brace negation (e.g. ek het dit nie gesê nie, see van Rensburg 1989: 147), and the non-standard Verb Second (V2) position of the

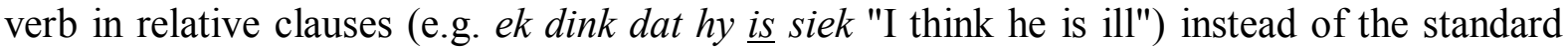
Verb Final position (e.g. ek dink dat hy siek is, see Ponelis 1993: 340-343). Afrikaans-English CS patterns can be contrasted at the grammatical level following a classification of switches into Muysken's (2000) grammatical types "insertion", "alternation" and "congruent lexicalisation" (for a thorough description, cf. Muysken 2000). They can also be contrasted at the conversational level following a categorisation of CS patterns as either indicative of a pattern of "one language at a time" (what Auer calls "code-switching") or the opposite (what he calls "language mixing").

Any adjustment or non-adjustment in the out-group context of speech patterns established at the in-group level will first tentatively be accounted for by means of CAT-based terminology, namely convergence, divergence or maintenance. Once convergence, divergence or maintenance is identified, it is open to question whether the adjustment or non-adjustment points upwards or downwards, or whether perhaps the interaction cannot be characterised as pointing upwards or downwards. Achieving clarity in this regard depends on the reconstruction of ethnolinguistic perceptions of the Other. It is also open to question to what extent convergence, divergence or maintenance are to be seen as relevant to the reconstruction of Coloured and White identities and not as simply cognitively motivated.

The final analysis is qualitative. It is conducted along general DA guidelines, and pays specific attention to the construction of Self and Other in the in-group and intergroup contexts, which it places against the qualitative background of the interview data, the feedback data, the various dynamics of convergence/divergence detailed during the contrastive analysis of speech patterns, as well as general knowledge on the current Namibian social context.

\section{Interview data}

All six participants are students at the University of Namibia and reside in Windhoek. The four Coloured students are aged 19 to 20; two are male and two are female; each is studying in a different field (two are enrolled in Education Sciences and Afrikaans, one in Visual Arts, one in Arts). They all speak Afrikaans as a home language, combined to varying degrees with 
English. They all enjoy exposure to Afrikaans at school, although sometimes at different stages, and all hold a self-reported high proficiency in English. These Coloured participants all have a South African Coloured ancestry, and are therefore not 'local Coloureds' (cf. Section 3).

The two White students are not acquainted with the Coloured students. They are aged 21 and 25; one is studying language and psychology, and the other Arts; both have Afrikaans-speaking parents, and speak Afrikaans as a home language; they have also received exposure to Afrikaans in education from Grade 1 up to Grade 4. Both have self-reported high proficiency in English.

None of the Coloured informants mentioned Afrikaans-speaking Whites in their close social networks, which they all described as dominantly Coloured. One White informant (A) mentioned Coloureds in her close social network, while the other $(\mathrm{C})$ described his close social network as almost exclusively White Afrikaans. All in all, Coloured perceptions of Whites seemed both positive (described as "polite") and negative (occasionally illustrated by narratives of White racism), whereas White perceptions of Coloureds seemed neutral, tending towards positive (described as "jovial").

Linguistic differences were specifically stressed on both sides. Coloureds generally stressed their use of Afrikaans-English CS, while feeling that Afrikaans speaking Whites use a distinct Afrikaans "accent" and also a distinct Afrikaans lexicon. In all cases, linguistic usage among White Afrikaans speakers was associated with Standard Afrikaans and was associated with less Afrikaans-English CS. Coloured opinions of the linguistic usage of White Afrikaans speakers range from descriptions of "correct" to "pompous", yet it could not be clarified whether those opinions referred to the use of Afrikaans features, such as accent, lexicon or grammar, or to the use of an Afrikaans monolingual code (i.e. without CS into English), or both (as we will see later, this lack of specification on the part of the participants will turn out to be problematic in the analysis of the speech data). All Coloured participants acknowledged feeling a need to adjust their linguistic usage to that of White Afrikaans speakers in intergroup encounters, thus suggesting an orientation to accommodating with the linguistic specificities of White Afrikaans speakers. At the same time, they claimed not to have mastered those specificities. Only two rated White/Standard Afrikaans as worth acquiring, while the others stressed the importance of acquiring English at the expense of acquiring White/Standard Afrikaans. Therefore, there is among the Coloured participants no systematic perception of White/Standard Afrikaans or of the linguistic usage of White Afrikaans speakers having high prestige.

As mentioned in the preceding section, only two out of the four Coloured students were asked to take part in the intergroup interaction ${ }^{7}$. Those two Coloured participants (B and D) represent the whole range of Coloured participants' perceptions presented above. B perceives White/Standard Afrikaans as "pompous" and not worth acquiring, and perceives White Afrikaans speakers as "racist". D perceives White/Standard Afrikaans as "correct", and worth acquiring, although not at the expense of English; D also perceives Whites as "polite".

\footnotetext{
${ }^{7}$ The reason for this arrangement is that we did not want to set up an inter-group interaction in which there would be an imbalance in numbers between Coloured participants and White participants, as a result of which the Coloured participants' attention might be deflected from communicating with the White participants. The reason why only two White participants were recruited has simply to do with the fact that there are very few White students on the UNAM campus, and the scope for finding more participants was therefore limited.
} 
Among the White participants, was the perception of Coloured linguistic usage being distinctive - and occasionally incomprehensible. Coloured usage was summarised as Coloured "slang" and marked by frequent Afrikaans-English CS. The White informants commented on Coloured slang with amusement, and both rated excessive CS negatively (although not in specific reference to Coloured usage). Participant $\mathrm{C}$ (the participant with a predominantly White Afrikaans network) acknowledged a need to linguistically adapt when interacting with Coloureds, suggesting an orientation towards accommodating with Coloured linguistic specificities. By contrast, A was not aware of feeling any need for adaptation, claiming instead that she is used to interacting with Coloureds. There were no specific indications that the White participants perceive Coloured linguistic usage as worth converging with for any other purposes than conveying humour or to aid interpretability. Coloured Afrikaans, or Coloured linguistic usage at large, seems to have low status in the eyes of the White participants. Unlike those Coloured participants stressing the need to acquire English at the expense of Afrikaans, both White participants stressed their attachment to Afrikaans, voicing concerns about the hegemony of English in Namibia.

In summary, these interview data provide evidence of a fairly negative intergroup history, mostly illustrated by the Coloured participants' occasional anecdotes of White racism. There is some scope on the basis of some of the Coloured participants' comments for depicting Coloured identity as a subordinate ethnolinguistic identity and White Afrikaans speaking identity as a superordinate one, although the emphasis placed by two of the Coloured participants on the need to acquire English at the expense of White/Standard Afrikaans could point towards a state of ethnolinguistic separation without subordination. This gives rise to two hypotheses:

- Coloured-White interactions within the Afrikaans speech community reflect unequal power distribution in favour of Whites, by virtue of which the Coloured participants are more oriented to converging with White linguistic usage than the other way around, in reflection of the typical cases of majority-minority relationships illustrated in Giles $(1978,1979)$. Convergence/divergence on the part of the Coloured participants can then be described as pointing upward and downward, respectively, whereas convergence/divergence on the part of the White participants can be described as pointing downward and upward, respectively.

- The White and Coloured participants both maintain their in-group linguistic usage. The possibility that the White participants may be oriented towards maintaining their in-group linguistic usage is suggested by the interview data, in which they did not evince any concern for converging with Coloured usage. The possibility that the Coloured participants may be oriented towards maintaining their in-group linguistic usage is suggested by knowledge of the current Namibian context, in which non-Whites in general may be coming to perceiving themselves as sociolinguistically equal to Whites.

In the next three sections we will examine the validity of those hypotheses on the basis of contrastive analyses of in-group and intergroup speech patterns.

\section{Contrastive analysis of White and Coloured in-group speech patterns}

Firstly, the investigation of morphosyntax did not reveal any conclusive quantitative evidence of a correlation between White usage and standard usage on the one hand, and between Coloured usage and non-standard usage on the other. Gradual variables that we investigated, 
namely the high frequency variables non-standard single negation versus standard negation and Verb Second (V2) in relative clauses versus Verb Last actually tended to show the opposite, in contradiction with the findings in Stell (2009). In other words, there is a higher occurrence of non-standard single negations and non-standard V2 in the White interaction than in the Coloured interaction ( $12.5 \%$ vs. $7.59 \%$ and 2 cases out of 35 vs. 0 case, respectively). Qualitative contrasts did, however, appear. Some of the gradual variables investigated in Stell (2011) occurred only in the Coloured interaction, such as accusative vir (e.g. ek sal probeer om vir hom uit te vang "I will try to catch him out") while they did not in the White interaction. Also, some of those ethnic features described in Section 5 occurred exclusively in the Coloured interaction, such as non-standard possessive pronouns (i.e hulle se "their" or julle se "yourPLUR" alongside hulle and julle), or ge-prefixation of verbs with an atonic prefix (i.e. gebegin alongside begin, "started"). Other features described as typically pertaining to Coloured varieties in the literature, and that occurred exclusively in the Coloured interaction, are the (non-generalized) duplicate use of locative prepositions (e.g. so jy is ook in my pa se kerk in? "so you are also at my pa"s church?").

A qualitative investigation of Afrikaans usage reveals a range of features again exclusively occurring in the Coloured interaction. Some of those features are lexical. One is the word $n \mid a^{8}$ ("good", "cool", "well"), not traceable to any specific language, which is adjectivally used as an attribute (e.g. hy gee nie nla informasie nie "he doesn"t give good information") or a

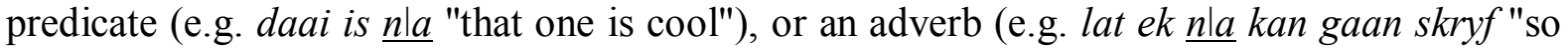
that I may be able to write well"). Another word, which qualifies more as a discourse marker on the grounds of its utterance-final position, is the word kau, again not traceable to any specific language, and used among other things as an intensifier in negative statements (e.g. ek ken nie kau "I really don"t know"), in affirmative statements with a function similar to that of indicator of shared knowledge ascribed to the Afrikaans adverb mos (e.g. daai hare is gister gedoen kau "that hair was done yesterday though wasn"t it?", see Jantjies 2009: 54-56). Typical of the Coloured interaction is the frequent use of the verb ken ("to know (someone)") in the sense of weet ("to know (something)") (e.g. ek ken nie instead of ek weet nie "I don"t know"). Among the phonological features occurring exclusively in the Coloured interaction is the post-alveolar affricate [d3], widespread in Western Afrikaans (Ponelis 1998: 15), which we find in lexicalized form in the $2^{\text {nd }}$ person subject pronoun $j y$ ([jei] "you"), occasionally pronounced as [dzei]. There is no feature of Afrikaans usage - morphosyntactic, lexical, phonological - that categorically distinguishes the White interaction from the Coloured interaction ${ }^{9}$.

Patterns of Afrikaans-English CS, on the other hand, reveal stark contrasts across the two interactions. One obvious contrast is quantitative, and can be observed mostly at both the intrasentential level ${ }^{10}$ and at the inter-turn level. At the intra-sentential level, Coloureds code switch much more than Whites. There is an average of $4.91 \%$ intra-sentential switches per hundred words in the Coloured interaction, as compared with $1.82 \%$ intra-sentential switches per

\footnotetext{
${ }^{8}$ The symbol $\mid$ is the standard symbol for dental clicks in Khoekhoegowab. We use this symbol here to reflect the pronunciation used by the participants. The word $n \mid a$ is, however, not a specifically Khoekhoegowab word.

${ }_{9}^{9}$ Stell (2009) found, however, categorical differences between Namibian White and Coloured Afrikaans morphosyntactic usage on the basis of quantitative data. One of those categorical differences concerns the use of modals in the past indicative. A construction such as ek kon dit doen ("I could do it"), which pertains to Standard Afrikaans, was found exclusively among Whites, whereas Coloureds would use constructions such as ek kon dit gedoen het (found among both Whites and Coloureds), or ek kan dit gedoen het in the same sense (found almost exclusively among Coloureds).

${ }^{10} \mathrm{We}$ use the term "sentential" here in reference to sentences in the narrow grammatical sense. The code-switches we refer to within sentential confines are insertions.
} 
hundred words in the White interaction. At the inter-turn level, the contrast is even sharper. That is, out of 727 turns in the Coloured interaction, there is a total of 151 all-English turns, which amounts to $20.77 \%$ of the interaction; 110 of these switches are clausal ${ }^{11}$, (as shown in example (1) below), and 41 are nominal (as shown in example (2) below). Contrasted with the inter-turn switches of the Coloured interactions, out of 315 turns in the White interaction, only 3 are all-English turns, that is $0.95 \%$, all of which are nominal.

D: Ek het 'n sms gekry.

I got an sms.

A: $\underline{\text { Congratulations }}$

C: Ja ok, maar ons het respect op 'n ander level.

Yeah ok, but we have respect at another level.

D: Ja me, I also do the same with my mom.

Contrasts also appear at the grammatical level of intra-sentential CS. Insertions tend to be more complex among the Coloured participants, involving determiner phrases (e.g. how many people het ek al doodgemaak? 'How many people have I killed already?'), prepositional phrases (e.g. hulle het dit gevat from the whites 'they took it from the whites'). Also, the share of within-turn alternations in the total of switches is more important in the Coloured interaction $(20.12 \%)$ than in the White interaction (7.7\%). One additional phenomenon not observed in Stell $(2009 ; 2011)$ is the occurrence of bidirectional CS (itself symptomatic of congruent lexicalisation, (cf. Muysken 2000: 132-3)), which occurs mostly in the Coloured interaction (cf. example (3), where the English alternation contains an Afrikaans insertion in the form of the prepositional phrase met die exams).

Wanneer is julle klaar? When are you done met die exams?

When are you done? When are you done with the exams?

Patterns of CS also differ across the two interactions in discourse functional terms. English alternations at the intra-turn level in the White interaction are used only for quotational purposes (4), whereas they tend to lack pragmatic functionality in the Coloured sample. The functionality of alternations in the White interaction suggests that CS in the White interaction reflects what Auer (1999) calls 'code-switching' (as opposed to 'language mixing', cf. Section 5). On the other hand, the lack of pragmatic function in individual switches in the Coloured interaction, added to the observation that the occurrence of an English alternation can trigger all-English turns (5), suggests that CS in the Coloured interaction reflects what Auer (1999) calls 'language mixing'. The sum of these observations related to interactional patterns of CS reflects the findings made in Stell (2011) on differences between White and Coloured patterns of Afrikaans-English CS.

\footnotetext{
${ }^{11}$ By 'clausal' all-English turns, we mean turns that comprise an utterance with a verb. We also count as 'clausal' all-English turns those instances of English turns comprising an English utterance to which an Afrikaans discourse marker may be appended, as illustrated in example (2) with the response $j a$ (which happens to be acknowledged as part of South African English). By 'nominal' all-English turns, on the other hand, we refer to those English turns which comprise single words or set expressions without a verb, as exemplified by (1).
} 
(4) Toe is ek soos: How is your baby mom? Toe is hy soos: No he is doing well, doing well. Toe begin lag sy.

Then I'm like: How is your baby mom? Then he is like: No he is doing well, doing well. Then she starts laughing.
A: Neh man maar daai was very complicated. There was like three interactions at one time going like (.) $\uparrow$ ok How do you write that?
No man that one was very complicated. There were like three interactions at one time going. Like ok? How do you write that?'
D: It's multitasking.

In summary, a cursory glance at linguistic and interactional patterns reveals contrasts between the White and Coloured interactions. Some linguistic features exclusively occurring in the latter could be treated as markers of Coloured ethnicity while other linguistic features occurring to different degrees in White and Coloured speech may not necessarily possess the pragmatic salience associated with ethnic markers. This might concern grammatical features such as, say, accusative vir, which is established as occurring in both White and Coloured speech, albeit more in the latter than in the former (Stell 2011). This might also concern CS, if form rather than function is taken into account (Both Coloureds and Whites use insertions, alternations and inter-turn CS, but they use them in different pragmatic functions). In the next section we will examine to what extent the presumed linguistic indexicality of features only occurring in the Coloured in-group interaction can support the interpretation of strategies of interaction between the White and Coloured participants as being relevant to the negotiation of White and Coloured identities.

\section{Convergence in the White/Coloured interaction}

One of our two hypotheses formulated in Section 6 was that orientation to convergence would be more likely to be found among the Coloured participants than among the White participants. This is the case to a large extent, as shown by the fact that the Coloured participants only exceptionally use Coloured Afrikaans features (we refer here to lexical and grammatical features and not to phonological ones except the post-alveolar affricate discussed in the preceding section) in the exchange, while the White participants overwhelmingly maintain their in-group patterns of Afrikaans usage. Also, the Coloured participants significantly reduce their patterns of inter-turn CS, while the White participants show no significant adjustment in this respect. While the White participants - just as in their in-group interaction - almost never use clausal all-English turns in the intergroup interaction, the Coloured participants use markedly less all-English turns in the intergroup interaction than in the in-group interaction: Only $0.91 \%$ of all turns taken by Coloured participant B in the intergroup conversation are allEnglish and clausal (vs. 5.76\% of all his turns in the in-group conversation), and only 3,66\% of all turns taken by Coloured participant D are all-English and clausal (vs. $23.56 \%$ of all his turns in the in-group conversation).

The sum of these preliminary observations of unilateral convergence reflects observations made with regard to interactions between members of a majority and members of a minority as described in Giles $(1978,1979)$ : Minority group members tend to converge with the usage of majority group members more than the other way around, since the linguistic usage of the majority group members is perceived as more prestigious. Coloured-to-White convergence in terms of Afrikaans usage and inter-turn CS could then be labelled upward convergence, 
whereas White-to-Coloured convergence could conversely be interpreted as downward convergence. This characterisation rests upon the assumption that Coloureds rank White usage higher than their own usage in terms of not only Afrikaans usage, but also CS patterns. The fact that CS involves English, that is, a language whose social status ranks higher than Afrikaans in the Namibian context, may upset this characterisation. We will, however, uphold this characterisation until our analysis of divergence/maintenance, where it will appear that the occurrence of Afrikaans-English CS may lend itself to an interpretation differing from the one we are offering here.

As we mentioned above, convergence in terms of Afrikaans usage overwhelmingly takes place in a Coloured-to-White direction. There is only one attempt on the part of a White participant at converging with Coloured Afrikaans usage. At the beginning of the intergroup interaction, White participant A jovially addresses Coloured participant D - whom she already knows by sight - using the characteristically Coloured post-alveolar affricate [dz] (cf. Section 6) in the $2^{\text {nd }}$ person pronoun $j y$ ("jou") in the question is dit jy? ("is this you?"). By asking D that question, her purpose is to confirm a relationship of acquaintance between her and $\mathrm{D}$, attempting by the same token to create social proximity by using a stereotypical Coloured pronunciation. A's attempt to identify with Coloured participants B and D is, however, met with embarrassed silence instead of an expression of social approval. This example may illustrate what Giles \& Coupland (1991: 79) describe as downward convergence perceived as "threatening" to listeners of the minority group to whose code the speaker converges. It could also be described as "crossing", to use Rampton's terminology (1995), and of an unwelcome sort. After that attempt, White-to-Coloured accommodation only involves CS patterns.

Quantitative evidence regarding intra-sentential CS does not point towards unilateral convergence as does the quantitative evidence for features of Afrikaans usage and inter-turn CS. Rather, it seems to point towards mutual convergence, in the sense that both Coloured participants use less English insertions in the intergroup interaction than in the Coloured ingroup interaction, while the White participants use more English insertions in the intergroup interaction than in the White in-group interaction (cf. Table 1). In the light of the quantitative evidence of unilateral Coloured-to-White convergence described above, as well as our decision to provisionally consider that Coloured usage is perceived as ranking lower than White usage in terms of both Afrikaans usage and CS, the adjustments observable in Coloured and White CS patterns are for the purpose of this section described as upward and downward convergence, respectively. Yet, unlike the instance of downward convergence where White participant A uses a Coloured Afrikaans phonological feature, that specific type of convergence on the part of the White participants does not seem to be met with disapproval by the Coloured participants.

Table 1. Number of English insertions per hundred words, participants A, B, C, D

\begin{tabular}{|l|l|l|l|l|}
\hline & A & B & C & D \\
\hline \multirow{2}{*}{ In-group } & 2.88 switches/100 & $\begin{array}{l}4 \text { switches/100 } \\
\text { words }\end{array}$ & $\begin{array}{l}1.41 \text { switches/100 } \\
\text { words }\end{array}$ & $\begin{array}{l}5.43 \text { switches/100 } \\
\text { words }\end{array}$ \\
\hline \multirow{2}{*}{ Out-group } & $\begin{array}{l}\text { word switches/100 } \\
\text { words }\end{array}$ & $\begin{array}{l}3.8 \text { switches/100 } \\
\text { words }\end{array}$ & $\begin{array}{l}2.5 \text { switches/100 } \\
\text { words }\end{array}$ & $\begin{array}{l}1.13 \text { switches/100 } \\
\text { words }\end{array}$ \\
\hline
\end{tabular}

The general observation that Coloureds adjust their patterns of CS is illustrated by those instances where, unlike in the Coloured in-group interaction, Coloured participants use Afrikaans repairs for English false starts. As in the in-group Coloured conversation, where 
Afrikaans and English clauses are freely juxtaposed, B starts her turn in example (6) with an Afrikaans clause, directly followed by an English clause (underlined) that does not perform any quotational function. But she interrupts that same clause and attempts to repair it with an Afrikaans one. Since using Afrikaans repairs can be seen as a departure from Coloured ingroup patterns (cf. Section 6), while using alternational Afrikaans-English CS might not have plausibly impacted the interpretability of the utterance by the White recipient, that repair sequence could be read as a conscious attempt to conform to the Afrikaans monolingual code associated with White Afrikaans speakers for social rather than for cognitive motives.

A: So hulle is not at all soos dieselfde So they are not at all like the same.

B: Jy sal nie die verskil sien nie but it's not the same (.) you won't (.) Jy sal dink o = You won't see the difference but it's not the same, you won't (...) you will think oh...

There are likewise several instances of Whites visibly accommodating to the Coloured participants' patterns of CS. When Coloured participant B explains to White participant A the origins of her family, she finds herself stuck within her Afrikaans utterance looking for a way to express the term 'British passport', as illustrated in (7). Her utterance stops at the use of the English adjective British, which she inserts with marked hesitation, in apparent failure to remember the Afrikaans equivalent (Brits(e)). By asking A "hoe sê mens?" ("how does one say that?"), she signals to A that she is looking for the Afrikaans equivalent. The question is whether she is looking for the Afrikaans equivalent in the stereotypical belief that adhering to a monolingual Afrikaans code is the norm among White Afrikaans speakers, and that emulating Afrikaans monolingual code is a requirement for winning social approval from A. Participant A, whom we already observed as particularly accommodating at the initial stage of the exchange, cuts B's hesitation short and validates B's performance-related choice for English by finishing B's utterance in English, instead of providing her with the Afrikaans term. She thereby avoids the negative attributions associated with upward divergence, or in other words, with the role of a 'language corrector'.

A: Maar enige ander familie in Skotland?

But any other family in Scotland?

B: Ja sy (.) sy antie sy niggie sy neefs (.) en daar is ook familie in Australia en dan sy broers is nog in Suid-Afrika (.) maar hul het al (.) hoe sê mens (.) British (...) Yes her aunt, her niece, her nephews, and there is also family in Australia and then her brothers are still in South Africa, but they all have how do you say British...

A: British passports

There are examples where the White participants' CS usage mirrors that of the Coloured participants across turns. In example (8), White participant A describes what she likes most about Walvis Bay, which is a local bakery, unknown to White participant $\mathrm{C}$. When $\mathrm{C}$ asks whether the place is new, Coloured participant $\mathrm{B}$ takes the floor to qualify the information given by A for the purpose of C's better understanding, specifying that the name Probst previously used by A - refers to a local bakery. The term she uses is bakery (underlined) instead of the Afrikaans equivalent bakkery. C gives A a backchannel response reiterating A's utterance, including the English noun bakery. While C's reiteration of bakery could be cognitively explained in terms of 'interactive alignment' (Kootstra et al. 2009), it could also again be interpreted as White participant $\mathrm{C}$ avoiding the attributions of what could be perceived as upward divergence. 


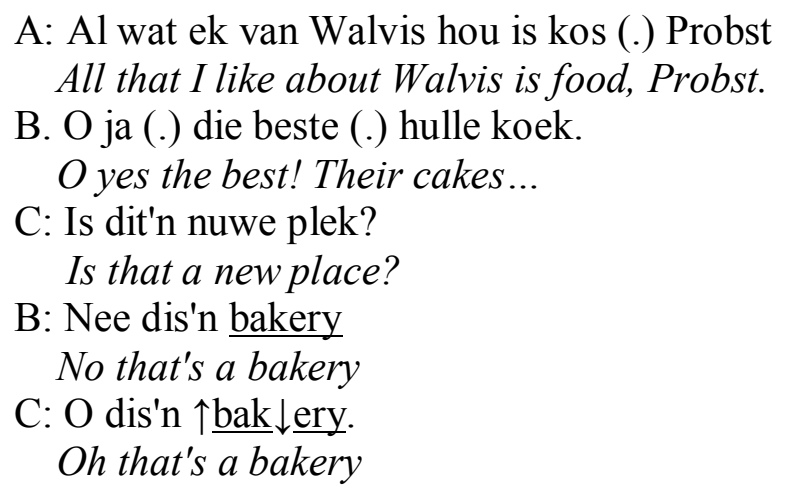

In summary, there is evidence of both unilateral Coloured-to-White convergence and of mutual convergence in the intergroup interaction. Whereas convergence is overwhelmingly unilateral in Afrikaans usage, it is not necessarily so in the case of CS patterns. We decided to rely on the assumption that the Coloured participant's perceptions of their usage ranking lower than White usage also include their CS patterns, by virtue of which their convergence with White usage generally qualifies as pointing upward, and White convergence with Coloured usage as pointing downward. As will turn out in the next section, it is only via instances of divergence via the use of English CS that the arbitrariness of this characterisation is revealed.

\section{Divergence/maintenance in the White/Coloured group interaction}

Divergence is mostly visible among the Coloured participants while the linguistic behaviour of the White participants tends - except at the level of intra-sentential CS - towards maintenance. Occasionally, divergence may involve the use of lexical features that we established as typically pertaining to Coloured varieties. An illustration of divergence with an identity-related function via the use of a Coloured Afrikaans feature comes in the form of the word $\underline{n \mid a}$ "cool". Coloured participant $\mathrm{D}$ makes use of that word in reaction to a comment by White participant A, in which she summarizes the confusion she makes between Coloureds and Basters, wilfully assuming the posture of the ignorant person that White participant $\mathrm{C}$ accuses her to be in the previous turn (9).

C: Jy moet'n educated citizen word You must become an educated citizen

A: $\uparrow>$ Man luister hier ek is 'n educated citizen ek het altyd history anderste om gehad ok? $=$

Man listen I am an educated citizen, my history has always been upside down ok?

$\mathrm{C}:=$ Weet jy wat het ek altyd gehoor?

Do you know what I have always heard?

$A:=\uparrow>$ Ek het gehoor die Coloureds kom van die Kaap af en êrens by Rehoboth het hulle vasgehaak en toe kry hulle 'n ander naam

I heard the Coloureds came from the Cape and got bogged down somewhere by Rehoboth and then got another name.

((general laughter among the Coloured participants))

$\mathrm{D}: \downarrow £$ vasgehaak (.) hy is nla.

Bogged down. That one is cool.

In his attitude, Coloured participant D may be validating the humorous thrust of A's posturing, but the use he makes of $n \mid a$ at that point could be read as a re-affirmation of Coloured identity in a context where Coloured identity is under discussion as a laughing matter. A confirmation 
of that identity-related function of $n \mid a$ is that $\mathrm{D}$ utters his interjection in a low key voice which contrasts with the high key voice in which White participant A took her previous turn, by which his own turn acquires a marked position within the sequence. By virtue of its status as a Coloured in-group lexical feature, $\underline{n \mid a}$ is more likely to carry pragmatic salience than variants that occur to differing degrees in both White and Coloured speech (cf. Section 6). This assumption may qualify the use of $n \mid a$ as an instance of downward divergence, which then fits Giles \& Coupland's description of downward divergence as among other things occurring in the speech of a member of a low status group who perceives his identity as being under threat from a member of a high status group (1991: 79).

There are among the Coloured participants some instances of linguistic divergence involving CS that seem to be more cognitively than socially motivated since the general orientation of the Coloured participants is toward accommodating with the White informants at those points in the exchange. In the later stages of the exchange, Coloured participant B assumes a leading role in the conversation by sharing with the White participants humorous moments of an English-speaking stand-up comedy show that she watched. In the process she quotes the comedians in English while keeping her narrative structure mostly in Afrikaans, in conformity with quotational CS patterns encountered in White and Coloured exchanges alike (cf. Section 6). At some points in her narration, however, English exceeds its quotational function by overflowing into the narrative structure itself, possibly under the effect of triggering. This is illustrated by (10), where B's English alternation (underlined) is all-English, non-quotational, and describes a situation in the stand-up comedy show. That informative function of B's alternation pragmatically contrasts with English alternations or English turns used by White participants. White participant C's all-English turn (underlined), for example, has an evaluative value while performing the conversational function of bringing the ongoing conversational frame to a close (cf. Alfonzetti 1998: 188-9 for 'closing sequences'), in line with the pragmatic functions associated with English inter-turn CS in the White in-group conversation (cf. Section $6)$.

(10) B: Nou maar as die vrou vir hom vra buy me shoes ok? But I have a savings account but

the cheque account can only be accessed.

But then when the woman asks him: Buy me shoes, ok? But I have a savings account but the cheque account can only be accessed.

A: Oh ok

C: Stand-up comedy caters

B: Het jy al vir Trevor Noah gekyk?

Have you ever watched Trevor Noah?

$\mathrm{C}$ : Waar kan ek sy nuwe een kry?

Where can I get his new one?

B: Ek weet nie maar ai wag tog (.) hy praat van'n wit vrou wat in'n shower is (.) dan kom iemand soos met'n mes agter en haar doodmaak dan daar is'n swart man and when the black woman comes out it's like pow pow.

I don't know but hey wait (.) he talks about a white woman who is in a shower (.) then somebody comes behind like with a knife and kills her then there is a black man and when the black woman comes out it's like pow pow.

What kind of divergence would this instance of CS represent? It would seem justified to describe it as pointing downward in view of (i) the fact that it forms an alternation of a discourse 
functional type only encountered in Coloured usage (cf. Section 6), and (ii) of the possibility that Coloured usage is perceived as ranking lower than White usage also in terms ofCS patterns (cf. Section 7). But should one then call White participant C's previous English turn an instance of downward convergence (towards the Coloured pattern of frequent inter-turn CS), even though - from the point of view of the sequence - it obviously does not proceed from a strategy of convergence (since it comes as a backchannel response to an utterance by Coloured participant B whose narrative structure is Afrikaans?). It seems possible that Afrikaans-English CS may be indexically ambiguous: While its functions might differ from White to Coloured usage, its forms do not allow a categorical distinction between the two. And whether it is the form rather than the function of CS - or the other way round - that indexes higher/lower prestige may be impossible to answer without more detailed participants' perceptions.

English turn-taking, another feature that we established as typical of Coloured AfrikaansEnglish CS, also illustrates the idea of CS being pragmatically ambiguous since it tends to come with an identity-related function in the intergroup interaction. In example (11), White participants $\mathrm{A}$ and $\mathrm{C}$ are involved in a dyadic exchange on the nature of an academic interview that $\mathrm{A}$ has just attended, and that $\mathrm{C}$ would also like to attend. In order to gain entry to that exchange, Coloured participant D inserts a question to A in English. His turn pragmatically contrasts with his previous Afrikaans turn. D's Afrikaans turn has the value of a backchannel as it only prolongs White participant C's turn, whereas his English turn introduces a new conversational frame, in which more elaboration of White participant A's experience is expected.

(11) C: Weet jy wat is dit dit is (.) die lecturers kyk na hoe die person optree en wat hy (.) en

wat hy in sy mind $(\ldots)=$

You know what is this (.) this is the lecturers look at how the person behaves and what he [has got] on his mind.

$\mathrm{D}$ : =hoe hy sou dit uitbeel $=$

How he would represent it.

A: =hoe interpretate hy

How he interprets.

D: And how do they judge you?

Characterising the English turn featured in (11) as downward divergence would fit a CAT scenario in only one respect: Its occurrence does not cause the White participants to respond in English. Instead, they maintain Afrikaans as the linguistic medium of interaction, thus exhibiting an orientation to maintenance typically associated with superordinate groups. For the rest, the context of its occurrence does not reflect the typical context of downward divergence, where the low status group member's identity is under threat. Coloured participant B's identity is not explicitly under threat by White participant A: A is only talking about a personal experience in which no identity motives are salient, and Coloured participant D just wants to keep her talking. Besides, an interpretation based on Myers-Scotton's Markedness Model (1993) suggests that we are not dealing with downward divergence here. By taking the floor in English, and holding it in English for the whole duration of his utterance, D may in fact be summoning the Rights and Obligations ${ }^{12}$ associated with English, which in the

\footnotetext{
${ }^{12}$ Rights and Obligations refer to 'a theoretical construct for referring to what informants can expect in any given interaction type in their community' (Myers-Scotton 1993: 23).
} 
Namibian context (as much as in the Kenyan context investigated by Myers-Scotton) can be seen as coupled with authority. In other words, D's English turns can be interpreted as a claim to a rightful role in the conversation in which he momentarily struggles to play a role. There is no example in CAT studies of downward divergence coupled to a High status language. Could it then be regarded as an instance of upward divergence ${ }^{13}$ ?

The quantitative and qualitative evidence of divergence that we detailed in this part illustrates the following ideas. Divergence on the part of the Coloured participants can be interpreted as cognitively motivated, but also as pursuing identity-relevant purposes. If it involves linguistic features that we established as pertaining to Coloured usage, it is likely to form instances of downward divergence. If it involves CS, it can be read as pointing either downward or upward, depending on the interpretation given to the Coloured participants' language perceptions. In certain contexts of the interaction, the case for calling downward divergence the use by Coloured participants of monolingual English code seems particularly weak. In the next section we will qualitatively show to what extent the notion of unequal sociolinguistic status distribution that we have sketched so far on the basis of, mostly, quantitative evidence of Coloured-to-White convergence and maintenance among the White participants, can be partly unsettled by a holistic view of the participants' discourses and feedbacks on the interaction in general, and by the pragmatic ambiguity of Afrikaans-English CS that those discourses and feedbacks confirm.

\section{9. 'Coloured' and 'White' ethnolinguistic identities: A qualitative perspective}

Participants' discourses in the in-group and intergroup exchanges illustrate distinct Coloured and White strategies of identity negotiation, which are reflected in distinct ethnolinguistic selfcategorisations. As we will see while referring to the participants' feedbacks on the interaction, the negotiation of White and Coloured ethnolinguistic identities in mutual interaction takes place in a field of mutually perceived tension in which the adjustment or non-adjustment of ingroup codes proceeds from mutually shared concerns for deference to which the distinction between upward and downward convergence/divergence may not be systematically relevant.

In the Coloured in-group exchange, we find evidence of insecurity inherent in Coloured identity when a social comparison with the White Other is involved. At a stage of the conversation where the participants' respective family backgrounds are under discussion, B engages in a social comparison of herself with the other participants on the basis of White background by remarking that every one of the participants has a White parent: "Het julle geweet ons almal het 'n witmens?" ("Did you know that we all have a White person?"). That comparison illustrates the perception of 'Colouredness' as a culturally hybrid identity shared by all participants. The in-between-ness of that identity is made salient by a pun addressed to B, after B remarks that her mother's hair is smoother than hers. In reference to the high social status of smooth hair among Coloureds, one of the other participants retorts to her: "Almal se hare is gladder as joune!" ("Everyone's hair is smoother than yours!"). Questioning the position of $B$ in the right middle of a phenotypical continuum ranging from White (with smooth hair as a physical attribute) to Black (with frizzy hair as a physical attribute) may be clearly humorous

\footnotetext{
${ }^{13}$ Giles (1979: 273) describes "upward divergence" only in reference to divergence by majority members: "...the greater the awareness of cognitive alternatives amongst Group A as to its social and linguistic superiority, and the greater the perceived vitality of Group B, the more likely members of the former group will be to differentiate linguistically from the latter by means of adopting more derogatory lexical markers of the outgroup and by creating new linguistic markers at other linguistic levels".
} 
coming from an in-group member, but it emphasizes the insecurity associated with Coloured group identity as an interstitial social category between Whites and Blacks, which Adhilkari (2005) detailed in-depth in reference to South African Coloureds.

No direct mention is made of White Afrikaans-speaking in-group identity in the White in-group exchange. However, mention is made of Others. They can assume the form of nationalities or ethnicities (e.g. 'German', 'Coloured', etc.), or they can assume the form of Namibia's government. Ex-president Sam Nujoma comes under fire from White participant A, who thereby signals her disaffiliation from the SWAPO-dominated Namibian political order, in reflection of the disaffection from post-apartheid concepts of nationhood observed among South African Whites (cf. Section 2). As it turns out, the construction of White identity among the White participants becomes more visible in the context of their interaction with the Coloured participants. We already noted this in Section 5 that A, for the emphasis she places on her history of contact with other ethnic groups and her awareness of conservative discourses within the White community that she disapproves of. This underlies her orientation toward preemptively dissociating herself from racialist discourses when the theme of language and ethnicity is brought up during the exchange. Upon discovering from the Coloured participants that participants were - for the purpose of this research - categorized in terms of ethnicity rather than language, she immediately signals to the Coloured participants her rejection of any possible association between language and 'race' in the Namibian context, thus suggesting that Coloureds and White Afrikaans speakers indisputably share a common ground in the form of Afrikaans.

We know on the basis of our interview data that the Coloured participants consider White Afrikaans speakers as Others. This may be confirmed at the moment when the topic of Coloured identity is brought up during the White-Coloured exchange. If there is any positive reception by the Coloured participants of White participant A's ethnically inclusive discourse, that positive reception is compromised by her curiosity about the distinction between Coloureds and Basters that she confesses not to know. Coloured participant B expresses annoyance at having to explain the distinction in a context where the two identities tend to be confused by outsiders. Receptive to the annoyance she brought about by her question, White participant $\mathrm{A}$ then enacts the role of an ignorant uneducated person by summarising her perception of Namibian Coloured history in a voluntarily bucolic fashion: Weren't they all Coloured at the beginning while some of them got another name when they got bogged down in Rehoboth? (cf. example 9). Even though she is engaged in playing down the distinction between White and Coloured, she just unwittingly posed a threat to Coloured identity. It is against the background of that threat posed by a member of a historically superordinate group that we found Coloured participant D suddenly erecting a linguistic boundary by using a Coloured ethnic marker. The erection of that boundary by Coloured participant D epitomizes A's momentary failure at playing down Coloured-White differences and confirms her perception by the Coloured participants as a 'White' Other and member of a 'threatening' superordinate group at that point in the exchange.

The motives of hybridity, in-between-ness, and insecurity with regard to in-group identity stand out in the in-group and intergroup processes of identity negotiation we observed among the Coloured participants. Isolation in Namibian society and concern about renegotiating intergroup boundaries while maintaining a symbolic attachment to Afrikaans are the motives pervading the negotiation of White identity among the White participants. The difference between these motives is reflected at the level of ethnolinguistic self-categorisation. While the 
Coloured participants categorized themselves as 'Namibian' and 'Coloured', the White participants categorized themselves as 'Namibian', 'White' and 'Afrikaans-speaking'. In other words, while there is a strong exclusive link between the White participants' identity and Afrikaans, the linguistic affiliation of Namibian Colouredness is not pinpointed. It seems instead to be subsumed in both 'Namibian-ness', of which the tacit linguistic attribute is English, and 'Colouredness', of which the linguistic attribute is Afrikaans-English language mixing rather than Afrikaans alone. By virtue of its connection to the language ranking highest in Namibian society, Coloured identity reflects at the in-group level an inclination for upward social mobility and integration that the use of monolingual Afrikaans code does not allow in the current Namibian context. This could explain why one Coloured participant described Afrikaans-English CS among Coloureds as a strategy 'to not forget English'. It is important to stress that the high status indexicality of Afrikaans-English CS is likely to vary across the continuum that ranges from intra-sentential Afrikaans-English CS up to the use of monolingual English code. In this respect, McCormick (2002) pointed out that Cape Peninsula Coloureds tend to consider Afrikaans-English intra-sentential CS as part of the vernacular (that carries ingroup values) and monolingual English code as a formal code. This is where the pragmatic ambiguity of monolingual English code as used by Coloureds might lie: It can be considered both as an extension of the vernacular and as distinct from it, thus potentially carrying both indexicalities.

We saw in Section 5 that some of the Coloured participants positively rated the usage of White Afrikaans speakers, without specifying whether they had Standard Afrikaans or monolingual Afrikaans code in mind. Allowing for an asymmetry between perceptions of Afrikaans varieties and of CS patterns, whereby CS patterns are attached higher prestige than monolingual Afrikaans code (because their connection to English allows them to summon 'Namibian-ness'), calls for a partial re-appraisal of the social indexicality of convergence/divergence in the intergroup exchange that we established in Sections 7 and 8. The use of certain phonological, lexical or grammatical features linked to Coloured Afrikaans within the White-Coloured interaction may be seen as 'downward' divergence if the Coloured participants attach higher prestige to Standard Afrikaans than to their own variety of Afrikaans. On the other hand, their use of Afrikaans-English CS may be labelled 'upward' divergence if it is attached higher prestige than monolingual Afrikaans code (cf. Section 8). That the avoidance by the Coloured participants of phonological, lexical or grammatical specificities of Coloured Afrikaans amounts to upward convergence makes sense in the light of the historically low prestige of Coloured Afrikaans varieties (cf. Section 2). The case for Afrikaans-English CS amounting to upward divergence is strengthened by the general feedback which Coloured participant $\mathrm{D}$ gave on the Coloured-White exchange: "We were scared of offending them". Offending them by 'talking them down' in English? But, if this is what D meant, aren't the Coloured participants' fears out of place in view of their knowledge that their White peers are also highly proficient in English, and were in a position to respond in English? The fact that the White participants were indeed in a position to respond in English, yet did not, is quite enlightening.

In the context of the White-Coloured interaction, there is a perception on both sides that the Other is Afrikaans speaking. Therefore, Afrikaans spontaneously offers itself as a linguistic vector of intergroup solidarity. Adhering to a monolingual Afrikaans code reflects the White participants' essentialist disposition towards their ethnolinguistic heritage. But an essentialist disposition may not explain everything. The White participants may also feel that switching to English as a medium of interaction may betoken a denial of the common ground they share with their Coloured peers. If that common ground may perceptually be preserved by using 
intra-sentential CS (which the White participants use more in the intergroup than in the ingroup conversation, see Section 7), it may not be perceptually preserved if monolingual English code is used. An indirect indication that we have in this regard is one of White participant A's comments in the feedback she gave on the interaction. She claims to disapprove of her White peers speaking 'Kitchen Afrikaans' to non-Whites for the sake of interpretability, as it conveys a 'lack of respect' according to her (an opinion shared by White participant C). Using 'Kitchen Afrikaans' with fellow Afrikaans speakers may - as much as the use of English monolingual code - convey a denial of social equality in their perceptions. Perhaps, then, the White participants' strategy of not complying with the Coloured participants' occasional use of English as a medium of interaction partly proceeds from a strategy of maintenance in which deference is a dominant motive (especially since it does not exclude convergence by means of intra-sentential CS).

Similarly, the Coloured participants may feel that imposing English, or even just AfrikaansEnglish intra-sentential CS, as a medium of interaction may erect an unnecessary boundary, while it may as well bring in its indexical values of post-apartheid order in which Whites are sidelined. Hence perhaps the fear of 'offending' the White participants expressed by D. Besides, there might be a fear on the part of the Coloured participants that erecting such a boundary might be seen as illegitimate. May 'talking down' a White Afrikaans speaker not be perceived as subverting a - perhaps still salient - sociolinguistic heritage of Whites forming the superordinate group and Coloureds the subordinate group? The dangers of sociolinguistic 'crossing' have already been described by Mesthrie (2009) in the South African apartheid context of tensions between Whites and Indians, where the use of White South African English by the latter was met with a negative response from the former. It is possible that both considerations, namely fear of offending and concern for legitimacy, were factors behind the (generally) converging CS patterns of the Coloured participants. Opting for Afrikaans as the medium of communication with White Afrikaans-speaking Others while pursuing conditions for favourable social comparisons may spur Coloured Afrikaans speakers to upward convergence with White Afrikaans usage. But whether Coloured-to-White or White-toColoured convergence involving Afrikaans-English CS is to be labelled 'upward' or 'downward' may not as yet be possible to answer in the current Namibian context where redistribution of sociolinguistic status in favour of English-speaking non-Whites is taking place.

\section{Conclusion}

Our CAT-based analysis of a Namibian Coloured-White interaction identified areas of linguistic convergence, divergence and maintenance, and linked them to strategies of identity negotiation. The CAT account we gave suggests that the White and Coloured participants' linguistic behaviours are typical of majority groups and minority groups, respectively. Such an interpretation may make sense in the light of the Apartheid socio-historical heritage of White domination over non-Whites, and if it refers only to Afrikaans usage, since Afrikaans Coloured varieties are established as possessing less prestige than White Afrikaans varieties. On the other hand, those patterns of CS that involve English turns may possess a vernacular indexical value as much as an indexical value of prestige, which the Coloured participants may summon in order to positively renegotiate their sociolinguistic status within the interaction. We saw in particular that monolingual English code is likely to perform that latter function.

A CAT account of the Coloured-White interaction as involving majority members (i.e. the Whites) and minority members (i.e. the Coloureds) may be justified in view of some 
quantitative evidence. But a qualitative holistic view of the data suggests that we are dealing here with a consensual pattern that the Coloured participants may occasionally feel uncomfortable with, yet are in a position to unsettle. The fact that strategies of upward divergence are available to the Coloured participants - in the form of English monolingual code - and that the availability of such strategies is made known to the White participants in the interaction may induce a sense that power relations within Namibia's Afrikaans speech community can be renegotiated by exogenous linguistic means. It remains to be seen whether that renegotiation of power relations - as we could occasionally observe it during the interaction - will ultimately lead to the wholesale adoption by Coloured Afrikaans speakers of English monolingual code for transactions with Namibian White Afrikaans speakers in a way that mirrors Scheffer's finding (1983) that Cape Peninsula Afrikaans-speaking Coloureds favour English for transactions with local White Afrikaans speakers.

\section{References}

Adhikari, M. 1996. Straatpraatjes. Language, politics and popular culture in Cape Town, 1909-1922. Pretoria: van Schaik.

Alfonzetti, G. 1998. Italian-dialect code-switching in Sicily. In P. Auer (ed.) Code-switching in conversation. Language, interaction and identity. 180-211. Cambridge: Cambridge University Press.

Auer, P. 1999. From codeswitching via language mixing to fused lects: Toward a dynamic typology of bilingual speech. International Journal of Bilingualism, 3(4): 309-332.

Bailey, B. 2007. Language and negotiation of ethnic/racial identity among Dominican Americans. Language in Society 29: 555-582.

Bell, A. 2001. Back in style: Reworking audience design. In P. Eckert and J. Rickford. Style and Sociolinguistic Variation. 139-169. Cambridge: Cambridge University Press.

Betzdorf, F. 2007. 'We don't have a culture'. Being coloured in Namibia als Konstruktion und Praxis. Kölner ethnologische Beiträge 25.

Beuke, C. 1997. Afrikaans in Namibië: Kontak en konflik. In: W. De Geest (eds). Recente studies in de contactlinguïstiek. 1-7. Bonn: Dümmler.

Britz, R. G. , H. Lang \& C. Limpricht 1999. Beknopte geskiedenis van die Rehoboth Basters tot 1990. Windhoek: Klaus Hess.

Bruwer, J.P. van S. 1964. Kleurlinge in Suidwes-Afrika. In: E. Theron and M.J. Swart (eds.) Die Kleurlingbevolking van Suid-Afrika.'n Verslag van'n komitee van die SuidAfrikaanse Buro vir Rasse-Aangeleenthede (Sabra) insake die Kleurlinge. Stellenbosch: Universiteitsuitgewers.

Burt, S.M. 1994. Coce choice in intercultural conversation: Speech accommodation theory and pragmatics. Pragmatics 4(4): 535-559.

Coetzee, E.R. 1982. Die geskiedenis van landelike vestiging van Blankes in Suidwes-Afrika, 1915-1931. M.A. Thesis. Johannesburg: Rand Afrikaanse Universiteit.

Du Plessis, H. 1987. Variasietaalkunde. Pretoria: Serva.

Fought, C. 2002. Ethnicity. In: J. K. Chambers, P. Trudgill \& N. Schilling-Estes (eds.) The handbook of language variation and change. 669-702. London: Blackwell.

Gallois, C. \& V.J. Callan. 1991. Intertehnic accommodation : The role of norms. In: H. Giles, J. Coupland and N. Coupland (eds.) Contexts of Accommodation. Developments in Applied Sociolinguistics. 245-269. Cambridge: Cambridge University Press.

Gallois, C. Ogay, T. \& G. Howard. 2005. Communication Accommodation Theory: A look Back and a Look Ahead. In. W. B. Gudykunst (ed.) Theorizing About Intercultural Communication. 121-148. Thousand Oaks, CA: Sage. 
Ganaseb, F. 2007. An investigation of Black Economic Empowerment (BEE) and its impact on development in Namibia. Unpublished M.A.Thesis. University of Stellenbosch.

Giles, H. 1978. Linguistic differentiation in ethnic groups. In: H. Tajfel (ed.) Differentiation Between Social Groups. Studies in the social psychology of intergroup relations. 361-394. London: Academic Press.

Giles, H. 1979. Ethnicity markers in speech. In: K.R. Scherer and H. Giles (eds.) Social Markers in Speech. 251-90. Cambridge: Cambridge University Press.

Giles, Howard, Richard Y. Bourhis, and Donald M. Taylor. 1977. Towards a theory of language in ethnic group relations. In: H. Giles (ed.) Language, ethnicity, and intergroup relations. 307-348. New York: Academic Press.

Horrell, M. 1970. The Education of the Coloured Community in South Africa, 1652-1970. Johannesburg: South African Institute of Race Relations.

Jantjies, W. 2009. The discourse marker mos in rural varieties of Afrikaans in the Western Cape: A descriptive study of syntactic patterns and pragmatic function. M.A. Thesis. Stellenbosch: University of Stellenbosch.

Kjæret, K. 2003. Rehoboth-Baster, Namibian or Namibian Baster? An analysis of national discourses in Rehoboth, Namibia. Nations and Nationalism, 9(4): 579-600.

Labov, W. 2001. Principles of Linguistic Change. Vol. II: Social Factors. Oxford: Blackwell. McCormick K. 2002. Language in Cape Town's District Six. Oxford: Oxford University Press. Milroy, L. 1987. Observing and analysing natural language. Oxford: Blackwell.

Muysken, P. 2000. Bilingual Speech. A Typology of Code-Mixing. Cambridge: Cambridge University Press.

Myers-Scotton, C. 1993. Social motivations of code switching. Oxford: Clarendon Press.

Odendaal, F.H. 1964. Report of the Commission of Enquiry into SWA Affairs/Verslag van die Kommissie van ondersoek na aangeleenthede van Suidwes-Afrika, 1962-3. Pretoria: Government Printers.

Prinsloo, K. P. 1982. Aspekte van taal- en kommunikasieaangeleenthede in SWA/ Namibië, vol. 1-13. Pretoria: RGN.

Rampton, B. 1995. Crossing: Language and Ethnicity among Adolescents. New York: Longman.

Roefs, M. 2006. Identity and race relations. In U. Pillay, B. Roberts and S. Rule (eds.) South African social attitudes: changing time, different voices. 77-100. Cape Town: HSRC Press.

Scheffer, P. 1983. Afrikaans en Engels onder die Kleurlinge in die Kaapprovinsie en in besonder in die Skiereiland. Pretoria: HSRC.

Schilling-Estes, N. 2004. Constructing ethnicity in interaction. Journal of Sociolinguistics 8(2): 163-195.

Schnee, H. 1920. Deutsches Kolonial-Lexikon. Vol. I. Leipzig: Quelle \& Meyer.

Sippel, F. 2004. Rechtspolitische Ansätze zur Vermeidung einer Mischlingsbevölkerung in Deutsch-Südwestafrika. In: F. Becker (ed.) Rassenmischehen - Mischlinge Rassentrennung. Zur Politik der Rasse im deutschen Kolonialreich. 138-164. Stuttgart: Franz Steiner.

Statistics South Africa 2001. Census in brief. 2nd Edition. Pretoria.

Stell, G. 2009. Recent Trends In Grammatical Variation In Afrikaans Varieties Within And Across Namibia's Borders. Stellenbosch Papers in Linguistics SPIL Plus, 39: 85-105.

Stell, G. 2011. Ethnicity and Language Variation: Grammar and Code-Switching in the Afrikaans Speech Community. Frankfurt a/Main: Peter Lang. 
Steyn, M. 2005. 'White Talk': White South Africans and the management of diasporic whiteness. In: A.J. Lopez (ed.) Postcolonial whiteness: a critical reader on race and empire. 119-136. Albany: State of New York Press.

Tötemeyer, A.J. 2010. Multilingualism and the language policy for Namibian schools. PRAESA Occasional Papers, 37.

Van Rensburg, M. C. J. 1989. Soorte Afrikaans. In: Botha T. J. R. (ed.) Inleiding tot die Afrikaanse taalkunde, 1st edition. 436-67. Pretoria: Academica.

Van Rooyen, J.W.F. 2000. Implementing Affirmative Action in Namibia. A summarized guide to the Affirmative Action (Employment Act) (Act 29 of 1988).

Wallace, M. and J. Kinahan. A history of Namibia. New York: Columbia University Press.

Webb, V.N. 1989. Die Afrikaanse variasietaalkunde. In T.J.R. Botha, F.A. Ponelis, J.G.H. Combrink and F.F. Odendal (eds.) Inleiding tot die Afrikaanse taalkunde. $2^{\text {nd }}$ edition. 412-36. Pretoria: Academica.

Weigend, G. 1985. German settlement patterns in Namibia. Geographical Review, 75(2): 156169.

Wilken, J.J.J. \& G.J. Fox. The history of the port and settlement of Walvis Bay, 1878-1978. Johannesburg: Perskor.

Wolfaardt, D. 2001. Facilitating learning: An investigation of the language policy of Namibian schools. Doctoral Dissertation. Bellville: University of the Western Cape.

Zietsman, P. H. 1992. Die taal is gans die volk. Pretoria: UNISA.

Zingelwa, A. 1999. The campaign for Khomasdal: The building of a Coloured community in Windhoek. In: W. Hartmann (ed.) More New Historical Writing in Namibia. History Research Paper No. 3. 22-36. Windhoek: Namibian History Trust at the Department of History, University of Namibia. 